\title{
Breeding Uniformity and Banking Diversity: The Genescapes of Industrial Agriculture, 1935-1970
}

accepted for publication in Global Environment, August 2016

\author{
Helen Anne Curry \\ Department of History and Philosophy of Science \\ University of Cambridge \\ Free School Lane, Cambridge CB2 3RH, United Kingdom \\ hac44@cam.ac.uk
}

\begin{abstract}
In the mid-twentieth century, American agriculturists began to fret about a growing threat to key economic crops: the loss or extinction of manifold local varieties, or landraces, resulting from the displacement of these in cultivation by recently introduced varieties that were better suited for industrial-style agriculture. Many breeders considered diverse landraces to be a valuable, and indeed essential, source of genetic material for their crop improvement efforts-and therefore an essential resource for the very system of agricultural production that appeared to threaten their continued existence. This paper explores how knowledge of this dilemma-that is, the reliance of industrial agriculture on genetic diversity that it tends to destroy-shaped efforts to conserve biological diversity and simultaneously shaped the landscapes and genescapes of twentieth-century agriculture. It takes maize (corn) as its central example, as it was changes in the landscapes of maize production, first in the United States and then across Latin America, which spurred an early international collaboration for the preservation of crop genetic diversity. As it shows with reference to this program and subsequent international developments in the conservation of crop diversity, the technology of the 'seed bank' was considered a crucial addition to the technologies of industrial agricultural production. It was understood to allow breeders to continue responsibly in the creation of high-yielding but ecologically vulnerable inbred crops by lessening the perceived risks inherent in the un-diverse landscapes of industrial monocrop agriculture.
\end{abstract}

KEYWORDS: biodiversity, genetic conservation, industrial agriculture, maize, seed bank

In the mid-twentieth century, American agriculturists began to fret about a growing threat to key economic crops such as maize (corn), wheat, and barley: the loss or extinction of genetically diverse varieties. As the United States Department of Agriculture (USDA) plant explorer Harry Harlan and botanist Mary Martini described in 1936, breeders had 'every reason to feel gratified' at their progress in creating improved crops and converting farmers 
to the use of higher yielding varieties. ${ }^{1}$ And yet they harbored concern about a problem created by these very successes. 'In a way we lose even when we gain', they wrote of barley breeding, which was their own specialty. 'Our old varieties... contained a large number of forms. The possibilities of finding additional strains of merit in these varieties are far from exhausted. But the acreage planted to them is shrinking rapidly. It will be difficult to maintain this particular reservoir of germ plasm in its entirety against the day when we may want it.' If through neglect the older varieties disappeared, then breeders in the future would be deprived of the potentially useful traits their genes might have conferred. Harlan and Martini's concerns extended beyond the loss of old American varieties to those traditionally cultivated in Africa, Asia, and Europe. 'The progenies of these fields with all their surviving variations constitute the world's priceless reservoir of germ plasm', but increased communication and trade meant that long-cultivated varieties were being replaced with imported improved seeds. The solution, in their view, was to create a collection where seeds of the hundreds of barley varieties that had entered the United States through the work of plant explorers and others could be 'preserved without loss' for the use of future breeders. ${ }^{2}$

The views articulated by Harlan and Martini in 1936 had already been put forward decades earlier, for example by the Austro-Hungarian agronomist Emanuel von Proskowetz who reported on the potential hazards of losing local landraces to the International Agricultural and Forestry Congress in Vienna in 1890 and by the German geneticist Erwin Baur who as early as 1914 expressed a worry about the loss of varieties not only in Europe

\footnotetext{
${ }^{1}$ In barley (Harlan and Martini's subject), such varieties included both homozygous lines of established landraces and hybrid types created by crossing two established varieties and then selecting superior progenies in subsequent generations.

${ }^{2}$ H. V. Harlan and M. L. Martini, 'Problems and Results in Barley Breeding', in Yearbook of Agriculture 1936, pp. 303-46 (Washington, DC: US Government Printing Office, 1936), quotations on pp. 315-17.
} 
but around the world. ${ }^{3}$ Such concerns grew stronger and more widespread over time, as reliance on improved commercial varieties became the norm in ever-more countries and as breeding techniques and agricultural technologies spurred the production of ever-more uniform crops. By the 1970s, agriculturalists fretted as much about the increased vulnerability of narrowly bred, high-yielding commercial varieties in a world with decreased 'genetic resources' as they did about disappearance of so-called indigenous varieties and landraces themselves. Both could be seen as endangered. ${ }^{4}$

In this paper, I explore how knowledge of this dilemma-that is, the reliance of industrial agriculture on genetic diversity that it tends itself to destroy-shaped efforts to conserve biological diversity and simultaneously shaped the landscapes and genescapes of twentieth-century agriculture. As with Harlan and Martini, many breeders' preferred solution to the possible loss of potentially valuable genetic types was not to maintain these in cultivation but to gather seeds of these varieties and arrange for their indefinite storage at seed storage facilities, today called 'seed banks' or 'genebanks'. The creation of these facilities, complete with technologies for cleaning, packaging and storing seed in refrigerated chambers, facilitated the migration of genetic diversity in crop plants from farm

\footnotetext{
${ }^{3}$ Christian O. Lehmann, 'Collecting European Land-Races and Development of European Gene Banks Historical Remarks', Die Kulturpflanze 29, no. 1 (Feb. 1981): 29-40. 30. For more on von Proskowetz and the changes in plant breeding and agricultural production that contributed to his interest in collecting landraces, see Jonathan Harwood, Europe's Green Revolution and Others Since: The Rise and Fall of Peasant Friendly Plant Breeding (London: Routledge, 2012), 37-50, esp. 45-47.

${ }^{4}$ The fullest historical account of interest in plant genetic resources is R. Pistorius and J. Van Wijk, The Exploitation of Plant Genetic Information: Political Strategies in Crop Development (Wallingford: CABI, 1999). See also Robin Pistorius, Scientists, Plants, and Politics: A History of the Plant Genetic Resources Movement (Rome: IPGRI, 1997); Timothy Farnham, Saving Nature's Legacy: Origins of the Idea of Biological Diversity (New Haven: Yale University Press, 2007), ch. 4; Marianna Fenzi and Christophe Bonneuil, 'From "Genetic Resources" to "Ecosystem Services": A Century of Concerns and Global Policies to Conserve Crop Diversity', Culture, Agriculture, Food and Environment, forthcoming.
} 
fields to laboratories, from geographically scattered cultivation sites to centralized scientific centers. $^{5}$

Although long overlooked in historical accounts of twentieth-century science and agriculture, seed banks have begun to receive greater attention. In recent publications, for example, historians have charted the development of seed collections as new 'cosmopolitan commons' in post-war Europe, examined breeders' interest in establishing such collections as archives of genetic diversity, and traced the emergence of the conservation of 'genetic resources' an object of international concern in the 1960s and subsequent transformations of this concern in international arenas. ${ }^{6}$

Here I examine the dual role of seed banks as agricultural technologies, emerging after World War II as essential elements of the technological assemblage of industrial agricultural production, and as conservation tools, envisioned as the best way to prevent the loss of endangered agricultural plants. I focus on maize, as it was changes in the landscapes of maize production, first in the United States and then across Latin America, which spurred an early international collaboration for the preservation of crop genetic diversity and the creation of several early long-term seed storage facilities. As I show with reference to this pan-American program, the technology of the seed bank was considered a crucial addition to the technologies of industrial agricultural production, one that lessened the perceived risks inherent in the un-diverse landscapes of industrial monocrop agriculture. By enabling the long-term conservation of varieties, seed banks were thought to allow

\footnotetext{
${ }^{5}$ A similar perspective is found in Thom Van Dooren, 'Banking Seed: Use and Value in the Conservation of Agricultural Diversity', Science as Culture 18, no. 4 (Dec. 2009): 373-95.

${ }^{6}$ See Tiago Saraiva, 'Breeding Europe: Crop Diversity, Gene Banks, and Commoners', in Nil Disco and Eda Kranakis (eds.), Cosmopolitan Commons: Sharing Resources and Risks Across Borders, pp. 185-211 (Cambridge: MIT Press, 2013); Sara Peres, 'Saving the Gene Pool for the Future: Seed Banks as Archives', Studies in History and Philosophy of Science Part C: Studies in History and Philosophy of Biological and Biomedical Sciences 55 (Feb. 2016): 96-104; Fenzi and Bonneuil, 'From "Genetic Resources" to "Ecosystem Services"'. For an earlier historical account, see Lehmann 'Collecting European Land-Races'.
} 
vulnerable inbred crops as these displaced more diverse progenitors in farm fields.

This paper brings together two histories that, despite their deep entanglement, are rarely told as one. ${ }^{7}$ The history of agriculture in the twentieth century is a story of industrialization and technologization, often characterized by emphasis on the increasing homogeneity of agricultural practices-and agricultural organisms-across regions and nations and then around the world. ${ }^{8}$ In many recent cases, scholars have charted the destructive consequences of this process (be they social or environmental) and implicated agricultural experts of many stripes in its unfolding, including breeders, entomologists, soil scientists, economists, water engineers, and still others. ${ }^{9}$ The history of biological

\footnotetext{
${ }^{7}$ Though there are not to my knowledge detailed accounts that bring together agriculture and the conservation of biological diversity as aligned activities, there are accounts that consider agriculture and its relationship to resource conservation, such as water and soil conservation. On the U.S. case, see, e.g., Neil Maher, Nature's New Deal: The Civilian Conservation Corps and the Roots of the American Environmental Movement (Oxford: Oxford University Press, 2007); Sarah T. Phillips, This Land, This Nation: Conservation, Rural American, and the New Deal (Cambridge: Cambridge University Press, 2007). For a short reflection on the link between diminishing genetic diversity in industrial agricultural animal breeds and efforts to preserve genetic diversity in these animals, see Joanna Radin, 'Planning for the Past: Cryopreservation at the Farm, Zoo, and Museum', in Fernando Vidal and Nélia Dias (eds.), Routledge Environmental Humanities: Endangerment, Biodiversity, and Culture, pp. 218-240 (Florence, KY: Taylor and Francis, 2015), via ProQuest ebrary.

8 James C. Scott, Seeing Like a State: How Certain Schemes to Improve the Human Condition Have Failed (New Haven, CT: Yale University Press, 2008), ch. 8. Surveys of global agricultural change that cover industrialization include Marcel Mazoyer and Laurence Roudart, A History of World Agriculture: From the Neolithic Age to the Current Crisis, translated by James H. Membrez (London: Earthscan, 2006); Mark B. Tauger, Agriculture in World History (Abingdon, UK: Routledge, 2011). Useful starting points on agricultural industrialization in the United States are Deborah Fitzgerald, Every Farm a Factory: The Industrial Ideal in American Agriculture (New Haven: Yale University Press, 2003); J. L. Anderson, Industrializing the Corn Belt: Agriculture, Technology, and Environment, 1945-1972 (DeKalb: Northern Illinois University Press, 2008); Paul K. Conkin, A Revolution Down on the Farm: The Transformation of American Agriculture since 1929 (Lexington: University of Kentucky Press, 2008).

${ }^{9}$ See, e.g., on breeding, Deborah Fitzgerald, The Business of Breeding: Hybrid Corn in Illinois, 1890-1940 (Ithaca: Cornell University Press, 1990); Jack Kloppenburg, Jr., First the Seed: The Political Economy of Plant Biotechnology, 1492-2000, $2^{\text {nd }}$ ed. (Madison: University of Wisconsin Press, 2004). On chemistry and soil science, see Vaclav Smil, Enriching the Earth: Fritz Haber, Carl Bosch, and the Transformation of World Food Production (Cambridge: MIT Press, 2004); Hugh S. Gorman, The Story of N: A Social History of the Nitrogen Cycle and the Challenge of Sustainability (New Brunswick, NJ: Rutgers University Press, 2013). On entomology, see Joshua Blu Buhs, The Fire Ant Wars: Nature, Science, and Public Policy in Twentieth-Century America (Chicago: University of Chicago Press, 2004); Pete Daniel, Toxic Drift: Pesticides and Health in the Post-World War II South (Baton Rouge: Louisiana State University Press, 2007). On water works, see John Opie, Ogallala: Water for a Dry Land, $2^{\text {nd }}$ ed. (Lincoln: University of Nebraska Press, 2000). Histories of agricultural assistance may often be generalized in the same way; see, e.g., Deborah Fitzgerald, 'Exporting American Agriculture: The
} 
conservation recounts the struggles of scientists, especially in the later twentieth century, against this very industrialization and homogenization, of efforts to save unique plants, animals, and ecosystems wherever their existence has been threatened. ${ }^{10}$ It is a history in which, until recently, little account was given of the role of technologies except as things to be rallied against. ${ }^{11}$ The story that I tell here reverses these more typical perspectives. On the one hand, it is a history of agriculture that emphasizes agricultural scientists' knowledge of and efforts to mitigate the potentially destructive consequences of their own homogenizing activities. On the other hand, it is a history of biological conservation that calls attention to how conservation might underwrite further industrialization and in fact hasten the destruction of living biodiversity, including through the promotion of new technological solutions.

\footnotetext{
Rockefeller Foundation in Mexico, 1943-1953', Social Studies of Science 16, no. 3 (Aug. 1986): 457-83; Joseph Eugene Cotter, Troubled Harvest: Agronomy and Revolution in Mexico, 1880-2002 (Westport, CT: Praeger, 2003); Nick Cullather, The Hungry World: America's Cold War Battle Against Poverty in Asia (Cambridge: Harvard University Press, 2010).

${ }^{10}$ The history of biological conservation after World War II is often told through the history of efforts to save wild animals and places. For this history in the United States, see, e.g., Thomas Dunlap, Saving America's Wildlife: Ecology and the American Mind, 1850-1990 (Princeton: Princeton University Press, 1991); Frederick R. Davis, The Man Who Saved Sea Turtles: Archie Carr and the Origins of Conservation Biology (Oxford: Oxford University Press, 2007); Mark V. Barrow, Jr., Nature's Ghosts: Confronting Extinction From the Age of Jefferson to the Age of Ecology (Chicago: University of Chicago Press, 2009); Etienne Benson, Wired Wilderness: Technologies of Tracking and the Making of Modern Wildlife (Baltimore: Johns Hopkins University Press, 2010); Kristoffer Whitney, 'A Knot in Common: Science, Values, and Conservation in the Atlantic Flyway' (PhD dissertation, University of Pennsylvania, 2012); Peter Alagona, After the Grizzly: Endangered Species and the Politics of Place in California (Berkeley: University of California Press, 2013).

${ }^{11}$ Recent histories have begun to explore the reliance of conservation biologists on technologies such as surveillance tools and captive breeding techniques and to chart the complications these entail for the protection of wild animals. See, e.g., Peter Alagona, 'Biography of a Feathered Pig: The California Condor Conservation Controversy', Journal of the History of Biology 37, no. 3 (Oct. 2004): 557-83; Benson, Wired Wilderness; Kristoffer Whitney, 'Domesticating Nature?: Surveillance and Conservation of Migratory Shorebirds in the "Atlantic Flyway"', Studies in History and Philosophy of Science Part C: Studies in History and Philosophy of Biological and Biomedical Sciences 45 (Mar. 2014): 78-87. The implication of automobiles in wilderness access and advocacy offers a different perspective on the intersection of technology and conservation activities; see Paul S. Sutter, Driven Wild: How the Fight Against Automobiles Launched the Modern Wilderness Movement (Seattle: University of Washington Press, 2002).
} 


\section{Improvement and imperilment}

Seed collecting and saving are activities with long histories, coextensive with the history of cultivation. Planting a crop at the start of one season presupposes that some seed has been gathered and set aside in anticipation of this planting, most likely during the harvest of the previous season. For most of human history, then, to be a cultivator was to be a seed saver, with the specific practices of seed collection and storage dependent on local knowledge and environmental conditions, as well as the demands of different crops. It was only in the twentieth century that the agricultural practices of seed saving and storage became, first, disassociated from the labor of farming and, subsequently, linked to concerns about the potential for permanent loss or extinction of particular genetic combinations.

The first of these changes has been well documented by historians. The creation of commercial markets for seeds and the increasing institutionalization and professionalization of breeding in the late-nineteenth century, especially in the United States and parts of Europe, gradually transformed seed production. The maintenance and improvement of varieties, once a farm-based activity, became the purview of agricultural experiment stations and commercial seedhouses. The methods of improvement shifted, too: away from mass selection, in which the seeds saved for future cultivation were drawn and mixed from the best plants of a particular harvest, and towards more involved approaches such as pureline selection, inbreeding and hybridization that aimed at producing new lines with specific desired traits. In the United States, varieties produced by the latter approaches, which were fostered by interest in the new science of genetics and supported by state investment, in time were seen to outperform older varieties. This contributed to both an expansion of commercial seed markets and increased genetic homogeneity among crops grown, as it encouraged a shift from the cultivation of heterogeneous, open-pollinated local varieties to 
genetically narrowed lines that were produced or maintained by others. In maize, the introduction of double-cross hybrid varieties based on the combination of four inbred lines beginning in the 1920s and 1930s facilitated exactly these transitions. Because hybrid vigor diminishes after the first generation while the inbred lines needed to produce hybrid seed are costly to maintain, farmers who wished to grow these hybrids needed to purchase their seed anew each season. And because the hybrids were derived from highly inbred stocks, their use meant increased genetic homogeneity among the plants of a particular variety both within and across farms. ${ }^{12}$

The second change, in which seed saving became a conservation activity, has been less extensively investigated. It took time for the concern about irreversible loss of genetic variations expressed in the early twentieth century to become widely shared-most likely because it took time for the changes they predicted to become apparent to most observers. Consider the case of maize production. Harlan and Martini were writing in the 1930s, just as double-cross hybrid maize was beginning to be adopted on a large scale in the United States. By the mid-1940s, this adoption was nearly complete. ${ }^{13}$ It was this changeover that finally induced a greater number of maize biologists and breeders to worry. With hybrids dominating the landscapes of US maize production, genetic diversity was no longer

\footnotetext{
${ }^{12}$ On plant breeding in the United States, including the story of hybrid corn, see Diane B. Paul and Barbara A. Kimmelman, 'Mendel in America: Theory and Practice, 1900-1919', in Ronald Rainger, Keith R. Benson, and Jane Maienschein (eds.), The American Development of Biology, pp. 281-310 (Philadelphia: University of Pennsylvania Press, 1988), http://www.mendelweb.org/MWpaul.html; Fitzgerald, Business of Breeding; Deborah Fitzgerald, 'Farmers Deskilled: Hybrid Corn and Farmers' Work', Technology and Culture 34, no. 2 (Apr. 1993): 324-43; Kloppenburg, First the Seed. For accounts of plant breeding in Great Britain, Germany, and France see, e.g., Paolo Palladino, 'Between Craft and Science: Plant Breeding, Mendelian Genetics, and British Universities, 1900-1920', Technology and Culture 34, no. 2 (Apr. 1993): 300-23; Paolo Palladino, 'Wizards and Devotees: On the Mendelian Theory of Inheritance and the Professionalization of Agricultural Science in Great Britain and the United States, 1880-1930,' History of Science 32 (Dec. 1994): 409-44; Thomas Wieland, 'Scientific Theory and Agricultural Practice: Plant Breeding in Germany from the Late $19^{\text {th }}$ to the Early $20^{\text {th }}$ Century', Journal of the History of Biology 39, no. 2 (Jul. 2006): 309-43; Christophe Bonneuil and Frédéric Thomas, 'Purifying Landscapes: The Vichy Regime and the Genetic Modernization of France', Historical Studies in the Natural Sciences 40, no. 4 (Fall 2010): 532-568; Harwood, Europe's Green Revolution and Others Since.

${ }^{13}$ Fitzgerald, Business of Breeding, ch. 6; Kloppenburg, First the Seed, ch. 5.
} 
maintained in situ by farmers growing different varieties in different regions. This in turn posed a practical concern for future breeding projects. For example, if a new pathogen were to threaten common maize varieties, where would breeders look for traits that might potentially confer resistance to that pathogen? Loss of diversity meant fewer avenues for breeders to pursue, which in turn meant increased vulnerability for crops and, ultimately, farmers. The concern extended to many crops: a 1946 meeting at the US National Academy of Sciences, intended to address the need for better maintenance of genetically diverse breeding stocks, brought together breeders working with 'barley, corn, flax, floriculture, fruits, grasses, legumes, oats, potatoes, soybeans, sugar beets, tobacco, [and] wheat'. ${ }^{14}$ The USDA, acting on the growing awareness of the trend toward uniformity and its consequences, initiated a 'New Crops' program in the late 1940s that aimed to bring in 'crop germ plasm' from around the world, to evaluate this germ plasm, and to maintain it. ${ }^{15}$ The latter was a novel step for the USDA, which had had global collectors for a long time but never a system for the permanent maintenance of collected items. At nearly the same time, the government provided funds for collecting the early open-pollinated maize varieties of the United States, assumedly because they were recognized to be both useful and rapidly disappearing. ${ }^{16}$ In 1950, a joint USDA and state experiment stations committee formally advocated the creation of a 'national seed storage unit' that would ensure that 'the national

\footnotetext{
${ }^{14}$ Landauer to Members of the Committee on Plant and Animal Stocks, 23 Nov. 1948, National Academy of Sciences (NAS), Biology \& Agricultural Division Files (B\&A), Folder: Comm. on Plant \& Animal Stocks, $1946-48$. See also, Landauer (1945) and "Proposed Plan for a Cooperative National Program [...]" (1946), National Records and Archives Administration, College Park, Maryland (NARA), Records of the Agricultural Research Service (RG 310), Division of Plant Exploration and Introduction, Plant Exploration Records, Box 9, Folder: COOP (RMA) Memorandum of Understanding.

${ }^{15}$ Sam Burgess, ed., The National Program for Conservation of Crop Germ Plasm (Athens: University of Georgia, 1971).

${ }^{16}$ W. L. Brown, 'Maize Germplasm Banks in the Western Hemisphere', in O. H. Frankel and J. G. Hawkes (eds.), Crop Genetic Resources for Today and Tomorrow, pp. 467-72 (Cambridge: Cambridge University Press, 1975), reference on p. 467.
} 
responsibility for the conservation of valuable germ plasm' would not be neglected as it sometimes had in the past; a new standing committee subsequently transformed this tentative recommendation into a formal set of proposals. ${ }^{17}$ As these institutional responses suggest, the perspective among American agriculturists about the need to harbor genetic diversity was changing. Many were beginning to feel alarm about the possible loss of useful types and to take steps towards potential solutions.

\section{From collection to conservation}

American agriculturists' concerns about dwindling diversity most often drew their attention beyond the borders of the United States, towards countries and regions better endowed with genetic diversity in key economic crops. This is evident in the activities of a small group of maize biologists and breeders who in the 1950s launched an international project dedicated to gathering, studying and preserving in perpetuity the many types of maize cultivated across the Americas. This conservation project was the first of its kind and strongly influenced subsequent global efforts to amass and preserve genetic diversity in various crops. A close examination of its unfolding illustrates how and why the creation of seed storage facilities, or seed banks, became the go-to solution for the problem of maintaining plant genetic diversity.

The history of this maize collection project begins with that of a different, and much better-known, agricultural program: the Rockefeller Foundation's Mexican Agricultural Program. In October 1943, the foundation entered into an agreement with the Mexican government in which it was to provide Mexico with technical expertise in agricultural

\footnotetext{
17 'Report of the Sub-committee on National Seed Storage', NARA, RG 310, Crops Research Division, New Crops Research Branch, Plant Exploration Records, 1953-1972, Box 6, Folder: National Seed Storage Laboratory 1957.
} 
research via a new American-staffed Office of Special Studies in the Ministry of

Agriculture. ${ }^{18}$ An early goal for staff at the Office of Special Studies was to establish

programs in crop plant improvement, as the creation of higher-yielding varieties possessing

greater disease- and drought-resistance promised a straightforward route to increased

agricultural production. Of the several crops slated for attention, maize was given priority.

This staple crop formed the basis of subsistence for many Mexican growers, most of whom

planted varieties that had been adapted for their locality over generations, with seed saved

from year to year. Many also struggled to produce enough from small land holdings that

often had poor quality soils and where drought was common. The foundation therefore saw

maize breeding as an ideal route to improving the lot of a large number of poor Mexicans

while also boosting overall agricultural production. ${ }^{19}$

One of the first activities to be undertaken in the maize-breeding program, which

was directed by the American geneticist and breeder Edwin Wellhausen, was to establish a

collection of Mexican maize types that would serve as the basis for developing and

distributing improved varieties. To gather samples of maize from across the country,

Wellhausen relied on the help of many assistants, mostly agricultural students from a

nearby university. By March 1944 the Office of Special Studies had assembled more than

400 samples; within five years, there were some 2000 . The collection represented the

\footnotetext{
${ }^{18}$ An early account of the Mexican Agricultural Program is found in E. C. Stakman, Richard Bradfield and Paul C. Mangelsdorf, Campaigns Against Hunger (Cambridge: Harvard University Press, 1967). Subsequent scholarly accounts include Fitzgerald, 'Exporting American Agriculture'; Bruce Jennings, Foundations of International Agricultural Research: Science and Politics in Mexican Agriculture (Boulder, CO: Westview Press, 1998); Cotter, Troubled Harvest; Karin Matchett, 'Plant Sciences Research and Agriculture in Mexico: Tensions and Collaboration Among Mexican and U.S. Scientists, 1935-1965', (Ph.D., University of Minnesota, 2002); Jonathan Harwood, 'Peasant Friendly Plant Breeding and the Early Years of the Green Revolution in Mexico', Agricultural History 83, no. 3 (Summer 2009): 384-410.

${ }^{19}$ On the importance of maize, see 'Agricultural Conditions and Problems', Report of the 1941 Survey Commission of the Rockefeller Foundation, Rockefeller Archive Center (RAC), Rockefeller Foundation Archives (RF), RG 1.1, Series 323, Box 1, Folder 2. On the maize-breeding program, see Karin Matchett, 'At Odds over Inbreeding: An Abandoned Attempt at Mexico/United States Collaboration to "Improve" Mexican Corn, 19401950', Journal of the History of Biology 39, no. 2 (Jul. 2006): 345-72; and additional references in fn. 18.
} 
extraordinary diversity of maize seen across Mexico. The cobs and seeds returned to the station came from plants that ranged widely in height, in the size of cobs, in color, in time to maturity, and so on, displaying 'an almost bewildering multiplicity' of different traits. ${ }^{20}$

Although the collecting effort had begun with the aim of providing stocks for the breeding program, it soon took on energy of its own. In 1948, staff of the Office of Special Studies gathered a small group of researchers to classify and describe the manifold varieties of maize they had gathered..$^{21}$ The publication of these studies, in Spanish in 1951 and in English in 1952 as Races of Maize in Mexico, was intended both to elucidate the evolutionary history of maize in Mexico and to make the collection a more useful resource for scientists and breeders across the Americas. It also identified a looming problem. The authors recognized that maize-breeding programs in Mexico, if successful, would produce types to replace the many diverse landraces they now encountered. Without farmers to grow these many historic and prehistoric strains of maize, and to save the seed from year to year, they would be lost. And they would be lost not only to Mexican farmers, but to breeders like themselves who relied on such diversity to carry out their work.

This conundrum encouraged a conservationist perspective among those examining the diversity in Mexican maize. As they wrote in the foreword to their book:

\footnotetext{
${ }^{20}$ E. J. Wellhausen, L. M. Roberts and E. Hernandez X. in collaboration with Paul C. Mangelsdorf, Races of Maize in Mexico: Their Origin, Characteristics and Distribution (Bussey Institution of Harvard University, 1952), foreword, pp. 9-10; Matchett, 'At Odds over Inbreeding', pp. 363-64; Stakman, et al., Campaigns Against Hunger, pp. 61, 260.

${ }^{21}$ In some ways, this project extended existing research programs. American biologists such as Paul Mangelsdorf and Edgar Anderson were already engaged in the study of maize diversity as a means of understanding its evolutionary history. Mangelsdorf, a consultant of the Rockefeller Foundation who had been integral to the launch of the Mexican Agricultural Program, participated in the initial classification efforts at the Office of Special Studies, while Anderson and others became involved as the collection and classification efforts grew. On the early classification effort, see Wellhausen et al., Races of Maize. See also individual recollections of the effort: Paul C. Mangelsdorf, Oral History, RAC, RF, RG 13, 69-73; Lewis M. Roberts, Oral History, RAC, RF, RG 13, 34-39; Edwin J. Wellhausen, Oral History, RAC, RF, RG 13, 133-43.
} 
Maize is the basic food plant in most of the Americas and its diversity... is one of the great natural resources of this hemisphere. To lose any part of that diversity is not only to restrict the opportunities for further improvement but also to increase the difficulties of coping with future climatic changes or with new diseases or insect pests. The modern corn breeder, therefore, has a responsibility not only to improve the maize in the country in which he works, but also to recognize, to describe, and to preserve for future use, the varieties and races which his own improved productions tend to replace and in some cases to extinguish. ${ }^{22}$

In other words, these researchers recognized the tangled relationship between their efforts to transform agricultural production and the imperative to conserve biological resources. Genetic diversity in crop plants was needed for the creation of improved varieties. But the success of these improved varieties in turn threatened genetic diversity, and demanded that efforts be made to protect such diversity so that crop improvement could continue in the future. The cycle was one that seemed likely to intensify. The greater the success in creating and disseminating improved varieties, the greater the threat to diversity, and therefore the greater the efforts at conservation that would have to be made.

The work undertaken to classify maize varieties within the Office of Special Studies soon catalyzed a much larger effort to collect, classify and preserve the diversity of American maize. One person who was particularly keen that such an effort be undertaken was the German geneticist Friedrich Brieger of the Universidade de São Paulo in Brazil. On encountering the Mexican maize work he became convinced that the study needed to be extended across all of Central and South America. ${ }^{23}$ In 1949 he spoke of this concern to the botanist Ralph Cleland, who was then chairman of the Division of Biology and Agriculture of the US National Research Council (NRC). Brieger's dire prediction-that many 'native strains

\footnotetext{
${ }^{22}$ Wellhausen et al., Races of Maize, foreword. This sentiment may have originated with Paul Mangelsdorf; see Edwin J. Wellhausen, 'The Indigenous Maize Germplasm Complexes of Mexico: Twenty-five Years of Experience and Accomplishments in Their Identification, Evaluation, and Utilization', in Recent Advances in Conservation and Use of Genetic Resources: Proceedings of the Global Maize Germplasm Workshop, pp. 17-28 (México: CIMMYT), reference on p. 17.

${ }^{23}$ Mangelsdorf, Oral History, p. 73.
} 
of maize' would 'be gone in ten years unless rescued'-convinced Cleland of the need to act. $^{24}$

Cleland's subsequent conversations with various well-positioned maize biologists and with the agricultural scientists of the Rockefeller Foundation resulted in the 1951 formation of a Committee on the Preservation of Indigenous Strains of Maize, run under the auspices of the NRC. This 'Maize Committee' moved rapidly to obtain a grant from the US Technical Cooperation Administration (TCA), a government agency whose Cold War mandate was to provide 'technical assistance' to developing countries, in order to finance a hemispheric effort to collect and preserve imperiled maize varieties. The committee believed that the loss of these varieties would be 'a major disaster' for several reasons, including: first, the loss of genetic variation needed to improve maize in Latin America; second, the loss of variation needed in the United States, where breeding programs were described as 'already reaching the point of diminishing returns'; and, finally, the loss of materials invaluable to researchers in disciplines ranging from anthropology to genetics. ${ }^{25}$

The Maize Committee decided that it would ensure continued access for breeders and other researchers to this crucial resource, genetic diversity, via the still-novel agricultural technology of dedicated long-term seed storage facilities. From its members' perspective, one would not want to stop the transition of Latin American farmers to higheryielding varieties. To do so would certainly stem the tide of varietal loss it perceived as threating. But this transition was seen as an inevitable-indeed, desirable!-change, one

\footnotetext{
${ }^{24}$ Cleland to Miller, 17 Dec. 1949, RAC, RF, RG 1.2, Series 300, Box 1, Folder 2.

25 'Proposed Plan for the Collection and Maintenance of Native Races of Maize' (undated), Harvard University Archives (HUA), Papers of Paul C. Mangelsdorf (PCM), HUG(FP) 37.10, Box 5, Folder: National Academy of Arts and Sciences, 1954- (1 of 2). A published account of the committee's work is J. Allen Clark, 'Collection, Preservation, and Utilization of Indigenous Strains of Maize', Economic Botany 10, no. 2 (Apr.-Jun. 1956): 194200.
} 
that would increase agricultural production across the region. Because the committee members wanted to encourage this agricultural shift, long-term or indefinite preservation of varieties as seed in centralized seed storage facilities appeared to be the only solution: a much-needed additional element of the technological system that undergird agricultural production. Once gathered and catalogued, seeds could be made accessible to breeders and other researchers around the world, assuming that some arrangement could be made for continuous storage, periodic renewal of stocks and distribution of seeds upon request.

In 1951, the Maize Committee imagined that it would require very little to set up and maintain such a facility. A refrigerated storage space was one essential component, 'sufficient to accommodate approximately 3000 4-oz. bottles' of seed, but it was far from enough to ensure the preservation of threatened maize varieties. Because seeds are living materials, which gradually lose their capacity for germination, they must be renewed at regular intervals by cultivating a crop and harvesting fresh seed. The committee estimated that a storage facility maintaining a few thousand varieties would therefore also need an acre of farm or garden land, which would provide enough space 'to grow 10-20 specimens of up to 600 strains of corn'. Cultivating maize varieties in order to replenish stocks obviously demanded ongoing seasonal labor, and this too had to be accounted for in the proposal. An initial estimate assumed that each variety in the collection would need to be grown out every five years to regenerate the seed, but that this and other stock maintenance activities 'would not require the full time of any one individual'. The committee's final estimated investment for a seed-storage facility of the desired size in Latin America was minimal: an initial cost of about $\$ 8000$ for equipment and $\$ 1500$ per year in maintenance (essentially, a year's salary for a station worker in Latin America). Those writing to the facility to request samples of any of the stocks held there would be expected 
to pay the costs of shipping themselves. Relying on these assumptions and calculations, the Maize Committee could easily imagine the creation of an endowment to support several new seed storage facilities, each of which would take on the task of not only storing but also continuously replenishing and distributing its stocks, in perpetuity. ${ }^{26}$

Out of the field and into the bank

The first task of the Maize Committee was collection. In addition to securing a three-year, US\$85,000 grant from TCA, it had also finalized a cooperative arrangement with the Rockefeller Foundation. The foundation, already on the ground in Latin America and by 1951 working with agriculturists in a number of countries besides Mexico, would supervise the collecting missions and provide land and space for multiplying and renewing the seed collections. The NRC, using TCA funds, would pay for equipment, supplies, travel expenses, and salaries associated with the collecting missions. TCA funds would also support the creation of three 'Seed Centers' for the collections-located in Mexico, Colombia and Brazil-with additional 'stand-by' storage made available at a USDA site at Glenn Dale, Maryland. Both the Mexican and Colombian Seed Centers would be affiliated with established Rockefeller Foundation operations. The Mexican center was to be located at Chapingo, the field site of the Office of Special Studies and home to Wellhausen's earlier maize collections. The Colombian center would be at Medellín, where a new Rockefeller Foundation initiative had been established in 1950 with objectives similar to those of the Office of Special Studies. In Brazil, the NRC entered into an agreement with Brieger's home institution, the Universidade de São Paulo, and placed Brieger in charge of the new Brazilian

\footnotetext{
26 'Proposed Plan for the Collection and Maintenance of Native Races of Maize' (see fn. 25). Administrators at the Rockefeller Foundation were skeptical of these estimates and more generally of the projected ease of keeping up stock collections; see, e.g., Barnard to Harrar, 17 Sep. 1951, RF, RG 1.2, Series 300, Box 1, Folder 2.
} 
Seed Center at Piracicaba. The collections at each of these sites would not be national, as the original Rockefeller Foundation collection of Mexican corn had been, but regional, with each hosting seeds from across a designated swathe of Latin America. ${ }^{27}$

Collecting missions in the regions designated for the Mexican and Colombian Seed Centers got underway almost immediately, in large part because of the existing infrastructure and networks put in place by the Rockefeller Foundation. By June 1952 the Mexico office had two full time collectors and a handful of students-all working under the direction of Wellhausen-scouring the many regions not covered by the Rockefeller Foundation's previous collecting activities. Wellhausen further reported having hired a man from Guatemala who had worked with the Mexico program to start collecting in that country. He had made similar arrangements for collection in Costa Rica and the rest of Central America. Meanwhile in Medellín, under the supervision of Lewis Roberts (director of the Rockefeller Foundation's agricultural program in Colombia), collection was said to be 'half-completed' ${ }^{28}$ At both Chapingo and Medellín, storage refrigerators were installed by the end of the year, technologies needed to keep the increasing numbers of seeds viable for longer periods of time. ${ }^{29}$ Things were much slower to get off the ground in Brazil, where Brieger was expected to coordinate collections throughout eastern South America. ${ }^{30}$ While this collecting work was ongoing in Central and South America, additional efforts were made

\footnotetext{
${ }^{27}$ Minutes of Meeting of Committee on Preservation of Indigenous Strains of Maize (Maize Committee), 26 Oct. 1951, NAS, B\&A, Folder: B\&A Agricultural Board Com on Preservation of Maize: Meetings, 1951-1958.

${ }^{28}$ Maize Committee (1952), Second Report, NAS, B\&A, Folder: B\&A Agricultural Board Com on Preservation of Maize: Reports, Progress, 1952-1954.

${ }^{29}$ Maize Committee (1952), Third Report, NAS, B\&A, Folder: B\&A Agricultural Board Com on Preservation of Maize: Reports, Progress, 1952-1954.

${ }^{30}$ The problems encountered in Brazil come up repeatedly in committee reports and internal correspondence. See, e.g., Mangelsdorf to Clark, 29 Apr. 1953, HUA, PCM, HUG(FP) 37.10, Box 5, Folder: National Academy of Arts and Sciences [sic], 1954- (2 of 2); Maize Committee (1953), Fifth Report, NAS, B\&A, Folder: B\&A Agricultural Board Com on Preservation of Maize: Reports, Progress, 1952-1954.
} 
to secure maize varieties in the islands of the Caribbean and in Canada and the United States. ${ }^{31}$ Maize Committee members were well aware that the vast majority of maize grown north of Mexico consisted of 'new hybrid corns' - types that were of little interest to the project-so here they focused on Native American communities where older openpollinated varieties were most likely to have survived. ${ }^{32}$

Regardless of who was collecting and where they were collecting, the basic plan for gathering and conserving maize seed was the same. A collector would travel to a region and collect cobs of maize from various sites, ideally about five of each type so as to ensure an adequate sample of seed, and then make an on-site description of the collected types. The cobs might be purchased at markets, gathered from Indian settlements or collected on commercial farms. Because it involved difficult travel, often through remote areas, collectors ended up spending weeks and months in the field. ${ }^{33}$ Once collections were made, the cobs were shipped back to the designated central storage facility-either Chapingo, Medellín, or Piracicaba-where they were to be measured and photographed, and then dried and shelled. The seeds were then further dried to a moisture level conducive to a long lifespan, packaged in airtight containers, and placed in refrigerated storage. ${ }^{34}$ The Maize Committee asked that small samples of each type be sent to the stand-by storage center. This facility would maintain a complete set of the collections from which varieties could be

\footnotetext{
${ }^{31}$ Maize Committee (1952), Third Report (fn. 29).

32 Maize Committee (1953), Seventh Report, NAS, B\&A, Folder: B\&A Agricultural Board Com on Preservation of Maize: Reports, Progress, 1952-1954.

${ }^{33}$ The case of the botanist and maize collector Victor Pantiño, who was dispatched to parts of South America, offers a good example of a typical collecting experience. See Maize Committee (1953), Fourth Report, NAS, B\&A, Folder: B\&A Agricultural Board Com on Preservation of Maize: Reports, Progress, 1952-1954.

${ }^{34}$ Maize Committee (1955), 'Collections of Original Strains of Corn, I', NAS, B\&A, Folder: B\&A Agricultural Board Com on Preservation of Maize: Collections of Original Strains of Corn: I.
} 
restored in the event of loss. ${ }^{35}$ The goal of amassing seeds of diverse types was quickly achieved. By 1955, the committee had amassed a total of 11,353 samples of maize from across the Americas, 10,922 of which had been officially catalogued. ${ }^{36}$

Unfortunately, it proved far easier to gather this massive collection than to arrange for its permanent maintenance. As early as July 1953, with the collections already substantive, the Maize Committee found itself wondering about the remaining 'problem' which included 'providing for periodic renewal, the classification, agronomic and genetic study of the collections, and the publications of the results of this research, and the cost of distributing the most promising collections to interested corn breeders around the world'. ${ }^{37}$ Ensuring that the seeds remained alive and in circulation-even beyond the terms of the grant, let alone in perpetuity as the committee members ultimately hoped-proved a significant challenge. The initial three-year grant from TCA had supported the creation of the three Seed Centers, including facilities for refrigeration, and the collection and preparation of seed stocks. The committee obtained a second three-year grant, which enabled research into the relationships among the many collected samples, their consolidation into a few hundred distinct 'races' of maize, and the publication of a series of books about these. ${ }^{38}$ However, the Maize Committee's efforts to fund an endowment to support the continued existence of the seed storage facilities, the maintenance of their

\footnotetext{
${ }^{35}$ Maize Committee (1954), Ninth Report, NAS, B\&A, Folder: B\&A Agricultural Board Com on Preservation of Maize: Reports, Progress, 1952-1954.

${ }^{36}$ Maize Committee (1955), 'Collections of Original Strains of Corn, II', NAS, B\&A, Folder: B\&A Agricultural Board Com on Preservation of Maize: Collections of Original Strains of Corn: II.

${ }^{37}$ Maize Committee (1953), Sixth Report, NAS, B\&A, Folder: B\&A Agricultural Board Com on Preservation of Maize: Reports, Progress, 1952-1954.

${ }^{38}$ Between 1957 and 1963, the NAS published ten titles on the 'Races of Maize' in different countries and regions of Latin America. These have been digitized and are available along with similar publications (and the original Races of Maize in Mexico) at www.ars.usda.gov/Main/docs.htm?docid=24766.
} 
stocks, and the distribution of seed on request were unsuccessful. ${ }^{39}$ Although it had assembled some of the infrastructure needed to address the loss of imperiled maize varieties, crucial elements remained out of reach. With the long-term survival of many thousands of seed samples dependent on the continued interest of the institutions that had initially been chosen to house these, the technology of seed-storage facilities looked at best like a precarious solution to the committee's concerns.

\section{Seed banks ascendant}

Perhaps one reason the Maize Committee was unable to convince funders to lay down resources for its Seed Centers was that these represented an as-yet untested technology. In the eyes of committee members and other collaborators, the need to preserve the extant diversity in maize was both obvious and pressing. Equally apparent was the solution of banking this diversity as seed. But living seed stocks, though less labor intensive to maintain than fields of crops from year to year, were by no means maintenance free. Nor were the mechanics of banking seed in this manner well worked out. What temperature and humidity would extend seed life the longest? How would renewal of collections, which required growing out a portion of an accession and allowing it to interbreed, affect their genetic composition? Was it necessary to maintain each accession of the thousands made, or would genetic diversity be equally well preserved in pooling accessions from across regions that were deemed to be of the same original 'race'? These and many other questions were mostly up for grabs, and not surprisingly so, as the proposal of indefinite seed storage for

\footnotetext{
${ }^{39}$ Rockefeller Foundation administrators bristled in 1953 when they encountered documents drafted by a member of the Maize Committee indicating that the Committee assumed that foundation staff and facilities would be used indefinitely for the maintenance and regeneration of stocks. See NRC, Maize Committee (1953), 'Proposed plan for a research grant [...]', October; Harrar to Clark, 5 Nov. 1953; and Harrar, memo, 16 Nov. 1953; both located in RAC, RF, RG 1.2, Series 300, Box 1, Folder 4.
} 
conservation purposes was still novel in the $1950 \mathrm{~s} .{ }^{40}$ The US government only approved funding for the construction of a long-term seed storage facility in 1957, after many years of petitioning on the part of interested agriculturists. The US National Seed Storage Laboratory (NSSL) was the first-ever facility, worldwide, built solely for long-term seed preservation. It did not hold working collections or maintain land and resources for the regeneration of seed stocks. It was simply a temperature- and humidity-controlled warehouse for valuable lines, designed to keep these from going extinct as a result of neglect or oversight. ${ }^{41}$

The insecurity felt by the Maize Committee as regards the future of its collection, and its faith in the technology of long-term seed storage as the solution to its conservation needs, can be seen in the rapidity with which it mobilized to secure space in the new NSSL. Even though construction of the facility was only just getting underway, the committee proposed in June 1957 that one-peck samples (15 pounds) of all the published races of maize be prepared for storage in the future NSSL, 'to insure a reserve seed supply available for future breeding and industrial uses'. ${ }^{42}$ This represented a considerable effort for those curating the collections in Latin America, but by 1961, 77 such samples had been prepared and sent to the NSSL, and more were to follow. ${ }^{43}$

\footnotetext{
${ }^{40}$ Current guidelines for seed banks offer a glimpse into the number and extent of biological aspects of seed maintenance to be investigated and operational protocols to be agreed upon; see, e.g., FAO, Genebank Standards for Plant Genetic Resources for Food and Agriculture (Rome: FAO, 2014), http://www.fao.org/3/ai3704e.pdf. Such guidelines have changed over time (and continue to change) as knowledge about seed longevity in storage and genetic drift within collections has developed.

${ }^{41}$ The NSSL would eventually provide a model and standard for equivalent national and international collections. On the NSSL, see Edwin James, 'Organisation of the United States National Seed Storage Laboratory', in E. H. Roberts (ed.), Viability of Seeds, pp. 397-404 (London: Chapman and Hall, 1972); George A. White, Henry L. Shands and Gilbert R. Lovell, 'History and Operation of the National Plant Germplasm System', in Jules Janick (ed.), Plant Breeding Reviews: The National Plant Germplasm System of the United States, pp. 5-56 (Portland: Timber Press, 1989).

42 Maize Committee (1957), Second Report, NAS, BA, Folder: B\&A Agricultural Board Com on Preservation of Maize: Reports Progress, 1956-1961.

${ }^{43}$ Sprague to Goodman, 21 Dec. 1967, NAS, BA, Folder: B\&A Agricultural Board Com on Preservation of Maize: General.
} 
The Maize Committee's seed storage facilities in Latin America and the NSSL shared as a central goal the preservation of potentially useful crop varieties from extinction-an aim that was still fairly unusual among institutions harboring seed collections in the 1950s and early $60 \mathrm{~s}^{44}$ They would not remain so for long. From the mid-1960s onward, biologists and agriculturists became increasingly worried about the loss of genetic diversity in crop plants. Whereas their expressions of concern about this issue had appeared intermittently from the turn of the twentieth century through World War II, these now coalesced into a continuous chorus of alarm. Many had observed the rapid globalization of improved varieties of the world's major crops, including maize, wheat and rice, transitions accelerated by the interventions of the Rockefeller Foundation and others in agriculture in many developing countries. And many increasingly feared that a global agricultural system founded on a narrow genetic base would be vulnerable to catastrophe. ${ }^{45}$

The latter fear took especially strong hold in the United States in 1970 following a disease outbreak in maize. A mutation in the fungus Helminthosporium - the agent of a disease known as Southern Corn Leaf Blight-gave rise to a virulent form that thrived on maize plants with a specific cytoplasmic genetic makeup. By 1970 some 85 per cent of maize grown in the United States carried genes for male-sterility, a trait that the need for the expensive and time-consuming process of detasseling when producing hybrid lines. Unfortunately the genes conferring this desirable trait had been derived from a lone Texas plant in the 1940s. And it was these same genes that were recognized in 1970 to be the source of maize's susceptibility to the more virulent form of Southern Corn Leaf Blight.

\footnotetext{
${ }^{44}$ The novelty of the NSSL concept can also be observed through the efforts that had to be made to convince American breeders to use it. See Eric E. Roos, 'Early History of NSSL and Contributions of Edwin James and Louis N. Bass', Journal of Seed Technology 17, no. 2 (1993): 25-40, reference on pp. 28-30.

${ }^{45}$ Pistorius, Scientists, Plants, and Politics; Farnham, Saving Nature's Legacy, ch. 4.
} 
Approximately 15 per cent of the American crop was lost that year, valued at an estimated 1 billion 1972 US dollars. ${ }^{46}$

The blight directed attention to the vulnerability created by genetic uniformity in crop plants. It led to renewed calls from breeders, biologists, agricultural economists and policymakers to acknowledge the dangers inherent in the trend towards uniformity and take steps to redress it, especially in major crops. The NRC quickly formed a Committee on Genetic Vulnerability of Major Food Crops to study the problem. In its final report, the committee recommended the greater use of 'exotic germ plasm' in breeding programs, in spite of the costs and challenges; they emphasized the need to harbor genetic diversity by ensuring the continuance of 'primitive varieties', 'local varieties' and the wild relatives of crops; and they called for continued efforts at plant introduction and support of the NSSL, while also encouraging the further development of living collections of genetically diverse varieties that would be more immediately accessible to breeders. ${ }^{47}$ In short, they demanded the further development and use of seed banks. This was the beginning of a period of more sustained attention to the issue of gathering and maintaining genetically diverse types in the United States, which would in turn lead to the expansion of the 'National Plant Germplasm System' in the 1970 s and 1980 s- with the NSSL at its center. ${ }^{48}$

Meanwhile there was also a growing determination to maintain and use global crop genetic diversity at the international level. One of the first organizations to respond to the increasingly vocal worries of plant breeders and conservationists was the Food and Agriculture Organization of the United Nations (FAO). In the mid-to-late 1960s, working in

\footnotetext{
${ }^{46}$ A. J. Ullstrup, 'The Impacts of the Southern Corn Leaf Blight Epidemics of 1970-1971', Annual Review of Phytopathology 10 (Sep. 1972): 37-50.

${ }^{47}$ National Academy of Sciences, Genetic Vulnerability of Major Crops (Washington, DC: NAS, 1972), ch. 16.

${ }^{48}$ See, e.g., description in Agricultural Research Service, The National Plant Germplasm System, Program Aid no. 1188 (Washington, DC: USDA, 1977).
} 
conjunction with the International Biological Programme (IBP), FAO organized a committee and a series of conferences to consider the exploration and conservation of 'plant genetic resources'. A 1967 FAO/IBP Technical Conference on the Exploration, Utilization and Conservation of Plant Genetic Resources resulted in one of the definitive early documents of this burgeoning conservation agenda, the IBP handbook Genetic Resources in Plants. As the handbook explained, the great variation seen within and across 'primitive' cultivars would not withstand the transition to 'modern scientific agriculture' with its emphasis on the creation of genetically uniform 'pure lines' and the spread of cultivation methods that 'minimize or even remove environmental differences over wide areas'. ${ }^{49}$ Though participants disagreed about the comparative virtues of ex situ versus in situ conservation strategies (e.g., seed banks versus continued cultivation) for imperiled cultivars and their equally threatened wild relatives, the conference report did, in the end, endorse the ex situ approach for reasons of practicality. 'There is... one need of general and overriding importance, and that is the need for international seed storage facilities', declared the introduction to the IBP handbook. ${ }^{50}$

The FAO/IBP conference participants clearly recognized that they were living through a time of dramatic change in global agricultural production. It was also a moment of dramatic change in the organization of international agricultural research. During the 1950s, the Rockefeller Foundation had extended its agricultural assistance programs throughout Latin America and then into South Asia and beyond. These efforts are usually described as

\footnotetext{
${ }^{49}$ O. H. Frankel, and E. Bennett, eds., Genetic Resources in Plants-Their Exploration and Conservation, IBP Handbook No. 11, (Oxford: Blackwell, 1970), pp. 7-9.

${ }^{50}$ Frankel and Bennett, Genetic Resources in Plants, p. 15.
} 
having launched the Green Revolution. ${ }^{51}$ By the 1970 s, now working with the Ford Foundation, the Rockefeller Foundation looked to further advance this agricultural agenda, not least by encouraging others to bankroll the kinds of on-site, research-driven programs they had come to believe would be most effective in addressing their shared concern-the 'world food problem'. Following a series of meetings initiated in Bellagio, Italy in July 1969, the foundations, together with the World Bank, FAO, UN Development Programme and backed by the governments of a number of developed countries, formed the Consultative Group on International Agricultural Research (CGIAR). This organization would coordinate international aid for agricultural research in developing countries, largely by channeling funds through a global network of agricultural research centers. The earliest of these research centers were four that had already been created by the foundations in preceding decades, including the International Rice Research Institute (IRRI, launched in 1959-60 in the Philippines) and the International Maize and Wheat Improvement Center (CIMMYT, founded in 1966 in Mexico but in many respects a continuation of the Rockefeller Foundation's earlier research organizations there). ${ }^{52}$

One of the first issues to arise within CGIAR as a pressing concern for global agricultural development was that of the conservation of plant genetic resources. In 1971, representatives from FAO put forward a proposal in which FAO, with funding from CGIAR and the assistance of other agencies and organizations, would lead and direct international efforts to collect and preserve crop genetic diversity. A central feature of the FAO plan was

\footnotetext{
${ }^{51}$ On the history of the Green Revolution, with particular attention to its geopolitical dimensions, see John $\mathrm{H}$. Perkins, Geopolitics and the Green Revolution: Wheat, Genes, and the Cold War (Oxford: Oxford University Press, 1997); Cullather, The Hungry World.

${ }^{52}$ The two other institutes were the International Institute of Tropical Agriculture (IITA, Nigeria) and the Centro Internacional de Agricultura Tropical (CIAT, Colombia). A brief history of CGIAR can be found in Pistorius, Scientists, Plants, Politics, 55-56; an institutional history of the founding and early years of CGIAR is Warren C. Baum, Partners Against Hunger: The Consultative Group on International Agricultural Research (Washington, DC: The World Bank for the CGIAR, 1986).
} 
the creation of eleven 'genetic resources centres', each of which would have facilities for seed storage and regeneration. ${ }^{53}$

Not all members of CGIAR were enthused by the plan, which precipitated further proposals from various different working groups and sub-committees over the subsequent two years. A major point of contention was the degree of control that would be granted to FAO. Officers of the Rockefeller Foundation, fearing a loss of influence, were particularly exercised about this issue. Their interest in the question of how genetic resources ought to be managed (and feeling of ownership over it) resulted from the foundation's prior investment in seed collection and conservation: not only had it been instrumental in amassing global diversity in maize during the growth and expansion of its Latin American agricultural programs, it had also sponsored collecting missions and long-term storage of wheat, rice, sorghum and the millets through these and other international agricultural programs since the 1950s. Foundation officials clearly wanted to retain significant control over these activities, though there is further evidence that they doubted the capabilities of the FAO to carry out the work effectively. ${ }^{54}$ Other significant items of contention that arose amidst the succession of proposals included the desired scope of the collections (that is, whether they should focus on the principal global economic crops or instead aim to gather a

\footnotetext{
${ }^{53}$ FAO, 'Proposal to Establish a Network of Genetic Resources Centres', presented at CGIAR TAC, Second Meeting, Rome, 19-22 Oct. 1971, http://hdl.handle.net/10947/973. There had been competing proposals prior to this point as well. See Baum Partners Against Hunger, pp. 79-82 and Pistorius, Scientists, Plants, Politics, ch. 4.

${ }^{54}$ See, e.g., Pino, memo, 15 Dec. 1972, RAC, RF, RG 1.3, Subseries 103D, Box 16, Folder 101. For further background on the activities associated with the World Germplasm Project, see Wortman, 'World Germplasm Project' and Minutes of the Meeting on the Status of Germ Plasm Collection, Preservation, Evaluation and Utilization, New York, 27-28 Sep. 1971; both in RAC, RF, RG 1.3, Series 103D, Box 16, Folder 101. See also Russell T. Johnson, 'Collection and Preservation of Food Crop Germ Plasm with Wide Genetic Diversity', Report prepared for CGIAR TAC, Second Meeting, Rome, 19-22 Oct. 1971, http://hdl.handle.net/10947/396.
} 
wider range of crop diversity) and what type of institutions these ought to be located within in (national or international, crop-specific centers or regional centers, and so on). ${ }^{55}$

What remained common to all of the proposals and counter-proposals that came before CGIAR was the assumption that collecting and maintaining crop varieties as seed in secure storage facilities would be the primary means of preventing the loss of plant genetic resources. The seed bank had achieved ascendancy, and was agreed upon as a technology essential to the continued success of world agriculture. Seed banks would subsequently be granted a central role in the international conservation efforts undertaken by a new International Board for Plant Genetic Resources, which was created under the auspices of CGIAR in 1973 and continues today (through a successor organization, Bioversity International) to be a leading organization in the management of global agricultural biodiversity. ${ }^{56}$

Subsequent decades have seen many incisive critiques of national and international seed banking activities, especially after the assertion of intellectual property rights in genetic resources (including crop varieties) and concerns about the global inequities arising from the transfer and ownership of such resources became international issues in the 1980s. ${ }^{57}$ In part because of such critiques, these decades have also witnessed surging interest in alternatives to the model of a centralized seed-storage facility under the control of breeder-scientists. Such alternatives range from in situ conservation programs that

\footnotetext{
${ }^{55}$ Several of the proposals are available online through the CGIAR historical archive. See, e.g., FAO, 'Proposal to Establish a Network of Genetic Resources Centres' (fn. 53); TAC Ad Hoc Working Group on the Conservation of Plant Genetic Resources, 'The Collection, Evaluation and Conservation of Plant Genetic Resources', presented at CGIAR TAC Third Meeting, Rome, 10-13 Apr. 1972, http://hdl.handle.net/10947/1523; CGIAR Subcommittee on Genetic Resources, Draft Report, Rome, 1-2 Oct. 1973, http://hdl.handle.net/10947/482.

${ }^{56}$ On the creation of IBPGR, see Pistorius, Scientists, Plants, Politics, ch. 4.

${ }^{57}$ For a detailed overview of these issues and international debates, see Keith Aoki, Seed Wars: Controversies and Cases on Plant Genetic Resources and Intellectual Property (Durham, NC: Carolina Academic Press, 2008).
} 
maintain diversity through continued cultivation of landraces, to nature reserves intended to harbor the wild relatives of economic crops, to community-operated ex situ seed banks that are maintained and used by local cultivators. ${ }^{58}$ Yet the vision of a seed bank as the ultimate technological solution for the specter of losing genetic diversity has hardly diminished. To grasp this, one need only consider recent large-scale, high-profile international endeavors such as the Svalbard Global Seed Vault, the so-called Doomsday Seed Vault dug into Arctic tundra on the Norwegian island of Spitsbergen, or the Millennium Global Seed Bank in Wakehurst, England, which aims to have 25 percent of the world's bankable seed by $2020 .^{59}$ Seed banks are indeed thriving.

\section{Conclusions}

It is not easy to situate the history of efforts to conserve the genetic diversity of agricultural crops within established narratives of the conservation of biological diversity in the United States. Crop plant conservators were more akin to earlier resource conservationists who championed water or soil conservation, in that they desired preservation for use above other concerns such as the intrinsic, non-instrumental value of plant and animal diversity or interest in the preservation of wildness. And yet the challenge they faced in successful conservation was better aligned with those protecting endangered species, for the threat to crop diversity resulted from same forces of industrialization and globalization, and from lack

\footnotetext{
${ }^{58}$ An introduction to in situ conservation of plant genetic resources is N. Maxted, B. V. Ford-Lloyd and J. G. Hawkes, eds., Plant Genetic Conservation: The In Situ Approach (Dordrecht: Kluwer, 1997); examples of such activities in various countries can be found in Stephen B. Brush, ed., Genes in the Field: On-Farm Conservation of Crop Diversity (Boca Raton, FL: Lewis Publishers, 2000).

${ }^{59}$ https://www.croptrust.org/what-we-do/svalbard-global-seed-vault; http://www.kew.org/scienceconservation/collections/millennium-seed-bank.
} 
of immediate economic value rather than overuse. ${ }^{60}$ The Maize Committee and those who shared its concerns worried about the potential hazards to human societies posed by the loss of biological diversity a couple decades before the 'endangerment sensibility' made this a common global sentiment. ${ }^{61}$ Individuals and organizations concerned about the loss of crop diversity successfully advocated for the integration of a complex and expensive conservation technology, the seed bank, into the very core of global industrial agricultural production. These and other unexpected elements of the history of seed banking suggest that it might help to frame new-and more diverse-narratives about the history of efforts to conserve biological diversity.

For example, this brief glance at the history of seed banking calls attention to the entanglement of industrial agriculture and global efforts to conserve biological diversity. The former is typically characterized by its dependence on genetically uniform crops and its ecologically destructive methods, and the latter as a struggle to mitigate the ill consequences of these and other industrial activities that destroy diversity-a struggle against the very forces that set global industrialized agriculture in motion. But industrial agriculture not only generated certain conservation concerns, it was also dependent (or its advocates came to see it as dependent) on conservation activities and tools. The American scientists whose research served as the foundation for vast mono-cropped fields of corn were also some of the first individuals to call for the global preservation of genetic diversity. In the case of the Rockefeller Foundation's agricultural assistance programs, it is clear that efforts typically implicated in a dramatic homogenization of the genetic constitution of crop

\footnotetext{
${ }^{60}$ A useful characterization of recent conservation priorities and values is Fernando Vidal and Nélia Dias, 'Introduction: The Endangerment Sensibility', in Fernando Vidal and Nélia Dias (eds.), Routledge Environmental Humanities: Endangerment, Biodiversity, and Culture, pp. 1-38 (Florence, KY: Taylor and Francis, 2015), via ProQuest ebrary.

${ }^{61}$ Ibid.; see also David Sepkoski, 'Extinction, Diversity, and Endangerment', in the same volume.
} 
plants around the world can also fairly be credited with organizing early efforts to collect and preserve the extraordinary genetic diversity of a few global crop species (regardless of how controversial those activities have since become).

This history also highlights the particularly paradoxical position of plant breeders who championed the conservation of genetic diversity and who celebrated their achievements in this arena as having saved endangered plants from extinction. Historians of science and environment have shown biologists to be not always straightforward heroes of biodiversity conservation: some became agitated about wildlife protection laws that interfered with their research practices, while others imposed ides about pristine and wild nature on places and especially peoples in insensitive, destructive ways. ${ }^{62}$ But in the case of preserving crop plant diversity, conservation and the artifacts it produced in fact underwrote the further destruction of the very object of conservation. Sustained efforts to collect and conserve crop varieties as endangered genetic resources emerged alongsideand, in some cases, as part of-the extension of more genetically uniform types over evergreater portions of the globe. Harboring the genetic diversity of plants became essential in a world where many people wanted crops plants to be as uniform and un-diverse as possible, whether to increase yield, enable the use of herbicides or pesticides, or facilitate mechanical harvesting and global shipping. The maintenance of genetic diversity, as a potential resource

\footnotetext{
${ }^{62}$ On scientists' irritation with environmental regulations that interfered with their research, see, e.g., Etienne Benson, 'A Difficult Time with the Permit Process', Journal of the History of Biology 44, no. 1 (Feb. 2011): 10323; Etienne Benson, 'Endangered Science: The Regulation of Research by the U.S. Marine Mammal Protection and Endangered Species Acts', Historical Studies in the Natural Sciences 42, no. 1 (Feb. 2012): 30-61. On conservation and accompanying harm to human cultures and communities, see, e.g., Mark David Spence, Dispossessing the Wilderness: Indian Removal and the Making of the National Parks (Oxford: Oxford University Press, 1999); Karl Jacoby, Crimes Against Nature: Squatters, Poachers, Thieves, and the Hidden History of American Conservation (Berkeley: University of California Press, 2001); and Dan Brockington, Fortress Conservation: The Preservation of the Mkomazi Game Reserve, Tanzania (Bloomington: Indiana University Press, 2002). A useful summary of the literature exposing the darker side of conservation is Dan Brockington, Rosaleen Duffy and Jim Igoe, Nature Unbound: Conservation, Capitalism, and the Future of Protected Areas (London: Earthscan, 2008), preface.
} 
in a bank, was seen as the only way to continue responsibly in creating these ever more uniform, ever more vulnerable, and ever more ecologically disruptive crops. And so, as genetic diversity diminished among crops in cultivation, it accumulated in containers and canisters, stowed away as seed in increasingly specialized facilities. These seed banks have become essential technological features of the landscape of industrial agricultural production: strange modern fortresses built to defend industrial crop varieties from the hazards generated by their own successes.

\section{Acknowledgments}

Some of the research for this project was made possible by a grant-in-aid from the Rockefeller Archive Center; I am indebted to the RAC for this support and further grateful to its ever-helpful staff for their invaluable assistance. For their many helpful comments and constructive feedback, I thank Jonathan Harwood, the editors of this special issue Donald Worster and Helmuth Trischler, Brenda Black, two anonymous reviewers, all of the participants in the May 2015 'Manufacturing Landscapes' conference in Beijing, and those individuals who attended seminar presentations of this research at the Max Planck Institute for the History of Science, Berlin, and LMU, Munich in October 2015. 